\section{REFERENCES}

1. Ayliffe GA. The progressive intercontinental spread of methicillin-resistant Staphylococcus aureus. Clin Infect Dis 1997;24(suppl 1):S74-S79.

2. Mulligan ME, Murray-Leisure KA, Ribner BS, Standiford HC, John JF, Korvick JA, et al. Methicillin-resistant Staphylococcus aureus: a consensus review of the microbiology, pathogenesis, and epidemiology with implications for prevention and management. Am J Med 1993;94:313-328.

3. Wenzel RP, Nettleman MD, Jones RN, Pfaller MA. Methicillin-resistant Staphylococcus aureus: implications for the 1990s and effective control measures. Am J Med 1991;91(suppl 3B):221S-227S.

4. The Hôpital Propre II Study Group. Methicillin-resistant Staphylococcus aureus in French hospitals: a 2-month survey in 43 hospitals. Infect Control Hosp Epidemiol 1999;20:478-486.

5. Romero-Vivas J, Rubio M, Fernandez C, Picazo JJ. Mortality associated with bacteremia due to methicillin-resistant Staphylococcus aureus. Clin Infect Dis 1995;21:1417-1423.

6. Spencer RC. Predominant pathogens found in the European Prevalence of Infection in Intensive Care study. Eur J Clin Microbiol Infect Dis 1996;15:281-285.

7. Vincent JL, Bihari D, Suter PM, Bruining HA, White J, Nicolas-Chanoin $\mathrm{MH}$, et al. The prevalence of nosocomial infection in intensive care units in Europe. Results of the European Prevalence of Infection in Intensive Care (EPIC) study. EPIC International Advisory Committee. JAMA 1995;274:639-644.

8. Aubry-Damon H, Legrand P, Brun-Buisson C, Astier A, Soussy CJ, Leclercq R. Reemergence of gentamicin-susceptible strains of methicillin-resistant Staphylococcus aureus: roles of an infection control program and changes in aminoglycoside use. Clin Infect Dis 1997;25:647653.

9. Girou E, Pujade G, Legrand P, Cizeau F, Brun-Buisson C. Selective screening of carriers for control of methicillin-resistant Staphylococcus aureus (MRSA) in high-risk hospital areas with a high level of endemic MRSA. Clin Infect Dis 1998;27:543-550.

10. Crossley K, Loesch D, Landesman B, Mead K, Chern M, Strate R. An outbreak of infections caused by strains of Staphylococcus aureus resistant to methicillin and aminoglycosides, I: clinical studies. I Infect Dis 1979;139:273-279

11. Ransjo U, Malm M, Hambraeus A, Artursson G, Hedlund A. Methicillinresistant Staphylococcus aureus in two burn units: clinical significance and epidemiological control. J Hosp Infect 1989;13:355-365.

12. Sheridan RL, Weber J, Benjamin J, Pasternack MS, Tompkins RG. Control of methicillin-resistant Staphylococcus aureus in a pediatric burn unit. Am J Infect Control 1994;22:340-345.

13. Bang RL, Gang RK, Sanyal SC, Mokaddas E, Ebrahim MK. Burn septicaemia: an analysis of 79 patients. Burns 1998;24:354-361.

14. Papia G, Louie M, Tralla A, Johnson C, Collins V, Simor AE. Screening high-risk patients for methicillin-resistant Staphylococcus aureus on admission to the hospital: is it cost effective? Infect Control Hos $p$ Epidemiol 1999;20:473-477.

15. Chaix C, Durand-Zaleski I, Alberti C, Brun-Buisson C. Control of endemic methicillin-resistant Staphylococcus aureus. A cost-benefit analysis in an intensive care unit. JAMA 1999;282:1745-1751.

16. Antibiogram Committee of the French Society for Microbiology. Official Statement 1999 [in French]. Pathol Biol (Paris) 1997;47:845-872.

17. Hospital Infection Society and British Society for Antimicrobial Chemotherapy. Revised guidelines for the control of epidemic methicillin-resistant Staphylococcus aureus. J Hosp Infect 1990;16:351-377.

18. Hospital Infection Society and British Society for Antimicrobial Chemotherapy. Revised guidelines for the control of methicillin-resistant Staphylococcus aureus infection in hospitals. J Hosp Infect 1998;39:253-290.

19. Sanford MD, Widmer AF, Bale MJ, Jones RN, Wenzel RP. Efficient detection and long-term persistence of the carriage of methicillin-resistant Staphylococcus aureus. Clin Infect Dis 1994;19:1123-1128.

20. Fierobe L, Decré D, Muller C, Lucet JC, Marmuse JP, Mantz J, et al. Methicillin-resistant Staphylococcus aureus as a causative agent of postoperative intra-abdominal infection: relation to nasal colonization. Clin Infect Dis 1999;29:1231-1238.

21. Boyce JM, Jackson MM, Pugliese G, Batt MD, Fleming D, Garner JS, et al. Methicillin-resistant Staphylococcus aureus (MRSA): a briefing for acute care hospitals and nursing facilities. The AHA Technical Panel on Infections Within Hospitals. Infect Control Hosp Epidemiol 1994;15:105115.

22. Coello R, Jimenez J, Garcia M, Arroyo P, Minguez D, Fernandez C, et al. Prospective study of infection, colonization, and carriage of methicillinresistant Staphylococcus aureus in an outbreak affecting 990 patients. Eur J Clin Microbiol Infect Dis 1994:13:74-81.

23. Cafferkey MT, Hone R, Keane CT. Sources and outcome for methicillinresistant Staphylococcus aureus bacteremia. J Hosp Infect 1988;11:136143.

24. Cookson B. Is it time to stop searching for MRSA? Screening is still important. BMJ 1997;314:664-665.

25. Teare EL, Barrett SP. Is it time to stop searching for MRSA? Stop the ritual of tracing colonised people. BMJ 1997;314:665-666.

\title{
Petroleum Ointment and Risk of Candidiasis in Low-Birth-Weight Infants
}

\section{Gina Pugliese, RN, MS \\ Martin S. Favero, PhD}

Researchers at Baylor College of Medicine, Houston, Texas, investigated an increase in the incidence of systemic candidiasis following a change in skin care for extremely-low-birth-weight infants in a 48 bed neonatal ICU (NICU). The skin-care change included the use of topical petrolatum ointment (TPO).

In a case-control study, 10 extremelylow-birth-weight infants with and 30 without systemic candidiasis admitted to the NICU from December 1, 1997, through July 31,1998 , were studied. A case was defined as an infant weighing $\leqslant 1,000 \mathrm{~g}$ at birth, with Candida species isolated from a normally sterile body site. Molecular analysis of Candida isolates was performed by karyotyping and restriction fragment-length polymorphism using pulsed-field gel electrophoresis.

The investigators found that case infants had a mean ( \pm standard deviation) age at onset of $21.5 \pm 24$ days. Infants with systemic candidiasis and controls did not differ in birth weight, gestational age, or duration of therapy with steroids, antibiotics, insulin, or total parenteral nutrition. Although cases were more likely to be born vaginally and had a longer duration of endotracheal intubation than controls, these differences were not significant. The odds ratio for skin care with TPO in case infants versus control infants was 11 (95\% confidence interval, 1.9-63). Skin care with TPO was discontinued, and the incidence of SC decreased to baseline.

The authors note that several Candida species and genetic profiles were identified, suggesting that there was not a common source outbreak but rather the use of TPO increased the risk of systemic candidiasis in extremely-low-birth-weight infants.

FROM: Campbell JR, Zaccaria E, Baker CJ. Systemic candidiasis in extremely low birth weight infants receiving topical petrolatum ointment for skin care: a case-control study. Pediatrics 2000;105:1041-1045. 